\title{
The Impact of the U.S. Rescue Plan on the Global Economy_Based on Input-output Method
}

\author{
Zhida Zhang \\ School of Economics, University of Chinese Academy of Social Sciences, Beijing 102488, China \\ zhangzhida@ucass.edu.cn
}

\begin{abstract}
The emergence of the new crown epidemic has impacted the global economy, and the United States, which is affected by the "herd immunity" policy, is no exception. GDP in 2020 has fallen by 2.3\% year-on-year. After Democrat Bi came to power, in order to restore the US economy, he proposed and finally passed the US\$1.94 trillion "U.S. Rescue Plan." This article sorts out the original text of the plan and compares it with ISIC4.0's industry categories, and then discusses the three transmission mechanisms of the plan's impact on the global economy. And using the input-output data in WIOD, the global input-output model is used to calculate its impact on the total output and GDP of countries and industries in the world. Studies have found that the US rescue plan has a significant impact on countries that have a large total trade volume with the United States, and has a greater impact on the global public health industry.
\end{abstract}

Keywords: American Rescue Plan, Global Economy, Input-output Method

\section{Introduction}

The new crown epidemic has caused a huge impact on the global economy, and the GDP of the world's major developed countries has declined to varying degrees. According to the Wind database, the GDP growth rates of developed countries such as the United States, Singapore, Japan, and the United Kingdom in 2020 will be $-2.3 \%,-8.8 \%,-4.0 \%$, and $-9.8 \%$ respectively. After U.S. President Biden took office, in order to help the U.S. economy quickly recover from the epidemic, he proposed an unprecedented "Build Back Better" plan ("Build Back Better"). The plan consists of three parts, namely the American Rescue Plan (The American Rescue Plan, with a total scale of US\$1.94 trillion, which was signed into law on March 11, 2021), and the American Employment Plan (The American Jobs Plan), The total scale of 2.28 trillion US dollars, has not yet been enacted), the American Families Plan ("The American Families Plan", the total scale of 1.86 trillion US dollars, has not yet been enacted). The total scale has reached 6.08 trillion yuan, accounting for about $30 \%$ of the US GDP in 2020.

\section{The Impact Mechanism of The U.S. Rescue Plan on The Global Economy}

The U.S. and other countries around the world have very close trade exchanges. The U.S. rescue plan will stimulate the import and export trade of various countries, thereby having a certain driving effect on the global economy. Take China as an example. According to statistics from the Ministry of Commerce of China, in 2020, the total value of bilateral trade in goods between China and the United States was 4.06 trillion yuan, an increase of $8.8 \%$, accounting for $12.6 \%$ of China's total import and export value during the same period. Among them, exports to the United States were 3.13 trillion yuan, an increase of $8.4 \%$, and imports from the United States were 931.87 billion yuan, an increase of $10.1 \%$. In addition, as table 1 shows, the top ten countries in the total import and export volume of the United States are China, Mexico, Canada, Japan, Germany, South Korea, the United Kingdom, Switzerland, Vietnam, and India. Countries with close trade relations with the United States are all within the scope of the database statistics of the world input-output table, which ensures the feasibility of the study.

The US rescue plan was proposed on January 14, 2021, and officially signed into law on March 11. The plan is mainly to directly provide residents with check subsidies (1,400 US dollars per person) and additional unemployment compensation subsidies (300 US dollars per person), supplemented by financial support for schools, hospitals, communities and other institutions. The total scale is about 1.94 trillion yuan. The dollar can directly increase the disposable income of American residents. The U.S. rescue plan can specifically affect the global economy through the following channels: The U.S. 
government issues unemployment benefits and cash vouchers to the residential sector. A small portion of the residential sector is used for savings, and most of it is used to purchase goods and services, thereby driving imports and exports. The development of trade; the US government grants direct loans to corporate departments, and companies invest funds in production and operations to stimulate import and export trade upstream and downstream of the industrial chain; the US government increases financial allocations to government departments (such as the Ministry of Health and the Department of Defense), and the government Used to purchase products and services, etc. All the mechanism is in figure 1.

Table 1 U.S. foreign trade (unit: million U.S. dollars)

\begin{tabular}{|c|c|c|c|c|c|}
\hline Rank & Nation & Export & Import & Total & Percentage \\
\hline-- & All countries & $1,431.60$ & $2,336.60$ & $3,768.20$ & $100.00 \%$ \\
\hline--- & Top 10 countries with the largest import and export volume & 910.70 & $1,658.00$ & $2,568.80$ & $68.40 \%$ \\
\hline 1 & China & 155.1 & 495.8 & 651.0 & $17.30 \%$ \\
\hline 2 & Mexico & 212.7 & 325.4 & 538.1 & $14.30 \%$ \\
\hline 3 & Canada & 255.4 & 270.4 & 525.8 & $14.00 \%$ \\
\hline 4 & Japan & 64.1 & 119.5 & 183.6 & $4.90 \%$ \\
\hline 5 & Germany & 57.8 & 115.1 & 172.9 & $4.60 \%$ \\
\hline 6 & South Korea & 51.2 & 76 & 127.2 & $3.40 \%$ \\
\hline 7 & U.K & 59 & 50.2 & 109.2 & $2.90 \%$ \\
\hline 8 & Switzerland & 18 & 74.8 & 92.8 & $2.50 \%$ \\
\hline 9 & Vietnam & 27.4 & 51.2 & 78.6 & $2.10 \%$ \\
\hline 10 & India & & 79.6 & 89.6 & $2.40 \%$ \\
\hline
\end{tabular}

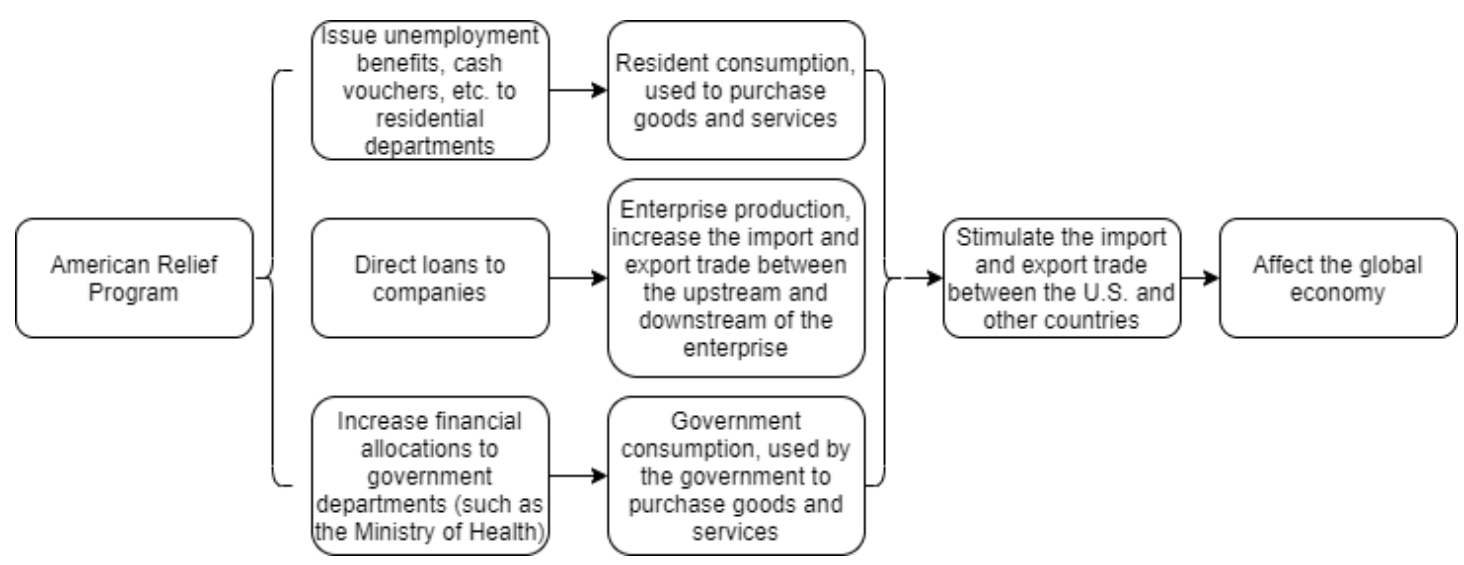

Figure 1 The influence mechanism of the U.S. rescue plan

\section{Literature Review}

The essence of the US rescue plan is a government investment behavior. Similar actions that are wellknown in history include the "Roosevelt" New Deal proposed by the United States in response to the Great Depression in the last century and China's "4 trillion" investment plan in response to the financial crisis in 2008. The academic research based on Roosevelt's New Deal is mostly based on the theoretical level, discussing the transformation of macroeconomic policy to Keynesianism. The success of Roosevelt' s New Deal not only opened up a precedent for state intervention in the economy in practice, but was also characterized by the government regulation advocated by Keynesianism. The modern macroeconomics of China kicked off (Xia Qingcheng, 1998). In addition, Roosevelt's New Deal also reflected the transition from a small government to a big government, changing the government boundaries of most countries in the world (Zi Zhongyun, 1998). In other words, the success of Roosevelt's New Deal demonstrated the need for the government to intervene in the economy during an economic crisis, and provided historical experience for people today and in the future to deal with economic recession.

The academic research on the four trillion investment is more focused on the calculation of its economic effects. Wang Xi and Lu Rong (2009) used the multiplier theory of the national income identity ( $\mathrm{Y}=\mathrm{C}+\mathrm{I}+\mathrm{G}+\mathrm{X}-\mathrm{M})$ to calculate the short-term contribution of government investment, but failed to consider the inter-sectoral correlation. And Leontief's input-output method is an excellent model for considering departmental linkages. Based on this theory, Guo Jue, Su Zhi, etc. (2009; 2013) used the input-output model to calculate the pulling effect of investment on the Chinese economy. Research is currently limited to the economic effect of investment on the country, and no one in the academic circle 
has studied the impact of investment on the global economy. Therefore, this article aims to study the impact of the US rescue plan on the global economy based on the world input-output table in WIOD.

The data comes from the original text of the White House law, and the original text of the bill corresponds to the industry categories of ISIC4.0. For consumption data that cannot directly correspond to the industry (such as the cash coupons issued by the US federal government), it was put into production in 2014 by the world. The structure of final consumption in the United States is decomposed and assigned to various industry categories. The final results are as follows. In addition, this paper also merges 56 industrial sectors from 43 countries in the WIOD database into 20 sectors according to major categories (for example, the data of the three industries A01, A02, and A03 are merged into the A industry) to facilitate subsequent calculations and analysis. Table 2 shows the distribution of funds by industry in the U.S. rescue plan.

Table 2 The distribution of funds by industry in the U.S. rescue plan

\begin{tabular}{|c|c|c|}
\hline Code & Industry name & $\begin{array}{l}\text { Amount (100 million } \\
\text { dollars) }\end{array}$ \\
\hline $\mathrm{A}$ & Agriculture, forestry and fishery & 65 \\
\hline $\mathrm{B}$ & Mining and quarrying & 116 \\
\hline $\mathrm{C}$ & Manufacturing & 1698 \\
\hline $\mathrm{D}$ & Supply of electricity, gas, steam and air-conditioning & 183 \\
\hline $\mathrm{E}$ & $\begin{array}{c}\text { Water supply; sewage treatment, waste management and } \\
\text { remediation activities }\end{array}$ & 4 \\
\hline $\mathrm{F}$ & Construction industry & 643 \\
\hline G & $\begin{array}{l}\text { Wholesale and retail trade; repair of automobiles and } \\
\text { motorcycles }\end{array}$ & 1480 \\
\hline $\mathrm{H}$ & Transport and storage & 498 \\
\hline $\mathrm{I}$ & Accommodation service activities & 1123 \\
\hline $\mathbf{J}$ & Information and communication & 648 \\
\hline $\mathrm{K}$ & Financial and insurance activities & 951 \\
\hline $\mathrm{L}$ & Real estate activity & 1330 \\
\hline $\mathrm{M}$ & Professional, scientific and technical activities & 395 \\
\hline $\mathrm{N}$ & Administrative and ancillary service activities & 87 \\
\hline $\mathrm{O}$ & $\begin{array}{l}\text { Public administration and national defense; compulsory } \\
\text { social security }\end{array}$ & 3230 \\
\hline $\mathrm{P}$ & Educate & 2214 \\
\hline Q & Human health and social work activities & 4253 \\
\hline R_S & Arts, entertainment and other cultural activities & 386 \\
\hline $\mathrm{T}$ & Family activities, undifferentiated activities & 11 \\
\hline $\mathrm{U}$ & Activities of international organizations and Institutions & 102 \\
\hline Total & Industry name & 19416 \\
\hline
\end{tabular}

\section{The Theoretical Model}

The simplified world input-output table is shown in the following table. The intermediate input is divided into 43 countries including the United States and China. Among them, the initial investment $I I=T S X P+E X P P_{-}$adj $+P U R R+P U R N R+V A+I n t T T M \quad, \quad T S X P \quad$ is Production tax amount, $E X P_{-} a d j$ is export adjustment, $P U R R$ is direct purchase by residents abroad, $P U R N R$ is non-resident domestic purchase, $V A$ is direct increase in value, IntTTM is international shipping profit.End use $Y=\mathrm{CONS}_{-} h+\mathrm{CONS}_{-} n p+C O N S_{-} g+G F C F+I N V E N, C O N S_{-} h$ is household final consumption, $\mathrm{CONS}_{-} n p$ is final consumption of non-profit organizations, $\mathrm{CONS}_{-} g$ is government final consumption, $G F C F$ is Gross fixed capital formation, INVEN is net change in inventory. This IO model is in table 3. 
Table 3 IO Model

\begin{tabular}{|c|c|c|c|c|c|c|}
\hline & \multicolumn{3}{|c|}{ Intermediate input } & \multirow{2}{*}{ End use } & \multirow{2}{*}{$\begin{array}{l}\text { Total } \\
\text { output }\end{array}$} \\
\hline & & America & China & Other countries & & \\
\hline \multirow{3}{*}{$\begin{array}{l}\text { Intermediate } \\
\text { input }\end{array}$} & America & & \multirow{3}{*}{\multicolumn{2}{|c|}{$A X$}} & \multirow{3}{*}{$Y$} & \multirow{3}{*}{$X$} \\
\hline & China & & & & & \\
\hline & $\begin{array}{c}\text { Other } \\
\text { countries }\end{array}$ & & & & & \\
\hline \multicolumn{2}{|c|}{ Initial investment } & \multicolumn{3}{|c|}{ II } & & \\
\hline \multicolumn{2}{|c|}{ Total investment } & \multicolumn{3}{|c|}{$X$} & & \\
\hline
\end{tabular}

$A$ is he direct consumption coefficient matrix, according to the row balance relationship of the input-output table, can be obtained:

$$
\begin{aligned}
A X+Y & =X \\
X & =(I-A)^{-1} Y \\
\Delta X & =(I-A)^{-1} \Delta Y
\end{aligned}
$$

$(I-A)^{-1}$ is the famous Leontief inverse matrix, the input-output analysis assumes that the matrix is stable, so it can be used to study the impact of one unit of final demand change on total output. That is to say, if we get the amount of investment in various industries from the US rescue plan, that is The corresponding impact on the total output can be calculated. Furthermore, we can also calculate the impact of the US rescue plan on the GDP of each country. The calculation method is as follows:

$$
\begin{gathered}
\Delta X=(I-A)^{-1} \Delta Y \\
\Delta G D P=A_{I I}(I-A)^{-1} \Delta Y
\end{gathered}
$$

$A_{I I}=\operatorname{diag}(I I) \bullet \operatorname{inv}(\operatorname{diag}(X))$.At this point, we can substitute the matrices $\Delta Y$ collected from the original text of the bill into $\Delta X=(I-A)^{-1} \Delta Y$ and $\Delta G D P=A_{I I}(I-A)^{-1} \Delta Y$, it is calculated how the US investment plan of 1.94 trillion yuan will affect the global economy. This impact is reflected in the pull on total output and GDP.

\section{Result Analysis}

Because time series analysis is not involved, this article only uses the 2014 global input-output table. Since the database contains input-output data of 56 sectors in 43 countries, the industry is divided into finer divisions. The author uses Python to convert the WIOD data Carry out the merger of industrial categories (for example, the merger of the three industries of A01, A02, and A03 in each country is recorded as A), a total of 20 industries. In addition, due to the large number of countries, the situation of some countries may be ignored in the analysis of the results.

\subsection{The impact of the US rescue plan on the total output of countries}

From table 4 we get that the US 1.94 trillion rescue plan will increase the world's total output by 3.47 trillion US dollars, with an output multiplier of approximately 1.79. Judging from the situation of various countries, the plan will have the greatest impact on the United States (because this is an economic stimulus plan launched by the United States), and will increase the country's total output by $\$ 3.1789$ billion, accounting for about $15 \%$ of the United States' GDP in 2020. Very impressive, of course, this does not mean that large-scale total output will increase within a year, but may gradually be reflected in the increase in output in the next few years. In addition, the five countries with the largest total output response to the rescue plan are China (44.856 billion U.S. dollars), Canada (34.246 billion U.S. dollars), Mexico (17.659 billion U.S. dollars), Germany (13.929 billion U.S. dollars), and Japan ( (US\$13.411 billion), these five countries are all the five countries with the largest import and export trade volume in the United States, confirming the transmission mechanism of the previous US rescue plan that mainly affects the global economy through import and export trade. 
Table 4 The impact of the US rescue plan on the total output of each country (unit: 100 million US dollars)

\begin{tabular}{|c|c|c|c|c|c|c|c|}
\hline Nation & $\begin{array}{c}\text { Change in } \\
\text { total output }\end{array}$ & Nation & $\begin{array}{c}\text { Change in } \\
\text { total output }\end{array}$ & Nation & $\begin{array}{c}\text { Change in } \\
\text { total output }\end{array}$ & Nation & $\begin{array}{c}\text { Change in } \\
\text { total output }\end{array}$ \\
\hline USA & 31788.76 & IND & 49.00 & TUR & 16.32 & GRC & 2.48 \\
\hline ROW & 767.20 & BRA & 46.73 & NOR & 14.11 & SVK & 2.23 \\
\hline CHN & 448.56 & RUS & 46.53 & AUT & 12.91 & LTU & 2.09 \\
\hline CAN & 342.46 & NLD & 42.76 & POL & 11.92 & BGR & 1.52 \\
\hline MEX & 176.57 & CHE & 37.01 & FIN & 11.14 & SVN & 1.03 \\
\hline DEU & 139.29 & BEL & 32.62 & DNK & 8.85 & HRV & 0.84 \\
\hline JPN & 134.11 & IRL & 29.72 & CZE & 7.55 & EST & 0.84 \\
\hline GBR & 107.79 & ESP & 28.13 & PRT & 5.13 & LVA & 0.57 \\
\hline KOR & 102.19 & AUS & 20.56 & HUN & 4.98 & CYP & 0.36 \\
\hline FRA & 68.31 & IDN & 18.29 & ROU & 4.48 & MLT & 0.27 \\
\hline ITA & 52.63 & SWE & 17.07 & LUX & 3.37 & & \\
\hline
\end{tabular}

We can also notice that there are seven countries that have contributed more than 10 billion U.S. dollars in total output. Compared with the first five countries, the United Kingdom and South Korea have been added. These two countries are both the top five to ten in the United States in total trade. s country. The impact on most countries is between 100 and 10 billion U.S. dollars, and there is basically no output boost to individual countries (Croatia, Estonia, Cyprus, Malaysia and others). Except for the countries counted by WIOD, the total output of the remaining countries is $\$ 76.72$ billion.

\subsection{The impact of the US rescue plan on the GDP of various countries}

The identity calculated by the national economy: GDP=total output-intermediate use, and the inputoutput model used in this article is an excellent tool to use this method to calculate GDP. Then we will discuss the impact of the US rescue plan on the GDP of various countries. By calculating the value-added coefficient, the changes in the GDP of each country can be obtained, as shown in table 5. 1.94 trillion U.S. dollars has the largest stimulating effect on the country's GDP, which is 1.81 trillion U.S. dollars, which is $93.30 \%$ of the total scale. The pulling effect is smaller than the scale of the economic stimulus, indicating that the funds of the plan may have flowed to other countries in the world through import and export trade.

In addition to the United States, the country with the largest GDP pulling effect is Canada, with a total scale of 16.544 billion U.S. dollars, followed by China (12.775 billion U.S. dollars), Mexico (8.465 billion U.S. dollars), Germany (6.14 billion U.S. dollars), and the United Kingdom (5.265 billion U.S. dollars) ), these countries are also the ten countries with the largest import and export trade with the United States. There are 29 countries with a GDP pulling effect of 100 to 10 billion U.S. dollars, 10 countries' GDP pulling total is less than 100 million U.S. dollars, and the rest of the world's GDP pulling effect is 31.731 billion U.S. dollars.

Table 5 The impact of the US rescue plan on the GDP of each country (unit: 100 million dollars)

\begin{tabular}{|c|c|c|c|c|c|c|c|}
\hline Nation & $\begin{array}{c}\text { GDP } \\
\text { changes }\end{array}$ & Nation & $\begin{array}{c}\text { GDP } \\
\text { changes }\end{array}$ & Nation & $\begin{array}{c}\text { GDP } \\
\text { changes }\end{array}$ & Nation & $\begin{array}{c}\text { GDP } \\
\text { changes }\end{array}$ \\
\hline USA & 18143.05 & BRA & 21.04 & SWE & 7.69 & LTU & 0.88 \\
\hline ROW & 317.31 & IND & 20.56 & TUR & 6.65 & LUX & 0.81 \\
\hline CAN & 165.44 & NLD & 19.96 & AUT & 5.27 & SVK & 0.79 \\
\hline CHN & 127.75 & ITA & 19.78 & POL & 5.00 & BGR & 0.61 \\
\hline MEX & 84.65 & CHE & 18.02 & FIN & 4.31 & SVN & 0.43 \\
\hline DEU & 61.40 & BEL & 12.76 & DNK & 3.82 & HRV & 0.40 \\
\hline GBR & 52.65 & IRL & 12.52 & CZE & 2.64 & EST & 0.34 \\
\hline JPN & 51.09 & ESP & 10.35 & PRT & 2.09 & LVA & 0.23 \\
\hline KOR & 34.12 & AUS & 9.68 & HUN & 1.99 & CYP & 0.16 \\
\hline FRA & 29.99 & IDN & 9.31 & ROU & 1.95 & MLT & 0.07 \\
\hline RUS & 21.85 & NOR & 7.75 & GRC & 1.17 & & \\
\hline
\end{tabular}


The greater the total trade volume with the United States, the greater the impact of the rescue plan. In order to see the relationship between economic impact and total trade more clearly, this article selects the ten countries with the highest total import and export volume with the United States, and compares the rankings of changes in total output and changes in GDP (Vietnam is not listed in the WIOD database). Statistics are performed, so the ranking is missing). In table 6 we found that the United States and China have the highest total import and export volume, and they are also most affected by the US rescue plan. The total output and GDP changes are ranked first and second respectively, followed by Mexico, which ranks second in total import and export volume. The rankings of output and GDP changes are both third. Countries with lower total imports and exports have less economic impact on their total output and GDP, such as Switzerland and India.

Table 6 Ranking of total trade and the influence of the United States

\begin{tabular}{|c|c|c|c|}
\hline Nation & $\begin{array}{c}\text { Ranking of total imports } \\
\text { and exports }\end{array}$ & $\begin{array}{c}\text { Ranking of total output } \\
\text { changes }\end{array}$ & GDP change ranking \\
\hline China & 1 & 1 & 2 \\
\hline Mexico & 2 & 3 & 3 \\
\hline Canada & 3 & 2 & 1 \\
\hline Japan & 4 & 5 & 6 \\
\hline Germany & 5 & 4 & 4 \\
\hline $\begin{array}{c}\text { South } \\
\text { Korea }\end{array}$ & 6 & 7 & 7 \\
\hline U.K & 7 & 6 & 5 \\
\hline Switzerland & 8 & 14 & 14 \\
\hline Vietnam & 9 & -- & -1 \\
\hline India & 10 & 10 & 11 \\
\hline
\end{tabular}

\subsection{The impact of the US rescue plan on the global industry}

After analyzing the economic impact of the US rescue plan on various countries around the world, let's look at its pulling effect on various industries around the world. As is shown in figure 2 and 3, from the perspective of total output, the five industries with the greatest pulling effect are $\mathrm{C}$ (manufacturing, USD 607.9 billion), Q (human health and social work activities, USD 434.5 billion), and O (public management and national defense; compulsory social security), 359.2 billion U.S. dollars), G (wholesale and retail; car and motorcycle repairs, 252.2 billion U.S. dollars), L (real estate activities, 249.2 billion U.S. dollars). From the perspective of GDP, it is still these five industries, but the ranking has changed. For example, the total output change of the manufacturing industry ranked first (607.9 billion US dollars, accounting for $17.54 \%$ ), while the GDP change ranking dropped to third (199.5 billion US dollars). US dollars, accounting for $10.33 \%$ ). It can be seen from these that the rescue plan is helpful to the development of industries such as human health, social work, and social security. The total output and GDP of the three are all higher than the impact on the manufacturing industry. Therefore, the impact on the global industry is mainly focused on promoting the provision of public services. From this perspective, it will help the world get out of the public health security crisis of the new crown epidemic as soon as possible. However, the scale of it is still not large enough if it is provided by the United States alone.

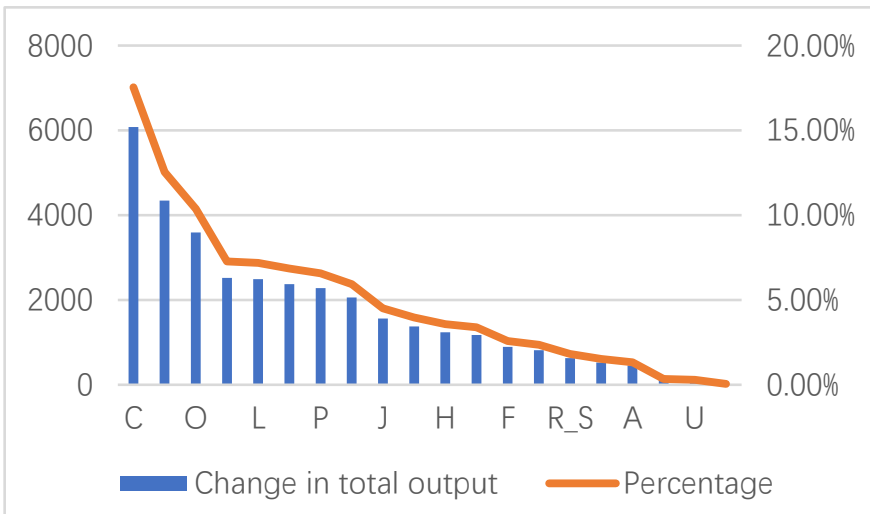

Figure 2 The impact of the US rescue plan on the total output of the global industry (unit: 100 million US dollars) 


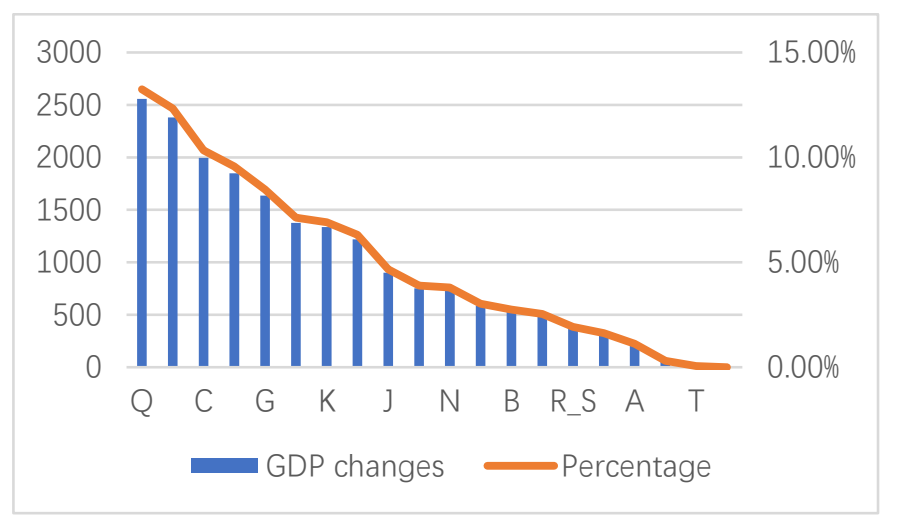

Figure 3 The impact of the US rescue plan on global industrial GDP (unit: US\$100 million)

\section{Research Conclusions}

The research in this article finds that the US 1.94 trillion economic stimulus plan will increase the total global output by 3.47 trillion yuan, of which the output to the United States will be 3.178876 billion U.S. dollars, and the output to China will be 44.856 billion U.S. dollars. The GDP of the United States increased by US $\$ 1.8143$ billion, and the GDP of China increased by US $\$ 12.775$ billion. Moreover, from a national level, the country with the larger total import and export trade volume with the United States will be more driven by the total output and GDP of the U.S. rescue program. From an industrial level, the U.S. rescue program has an impact on global public health-related industries. (Such as human health and social work activities, public management and national defense, compulsory social security, etc.), the total output is 10,042.4 billion U.S. dollars, and the total GDP is 493.9 billion U.S. dollars, all of which exceed the pull of the manufacturing industry. effect.

\section{References}

[1] Xia Qingcheng, Jian Mingjun. The Great Depression and Roosevelt's New Deal in the 1930s in the United States[J]. Financial Research, 1998 (12): 37-42+45.

[2] Zi Zhongyun. Also on Roosevelt's "New Deal"[J]. International Economic Review, 1998(Z4): 21-24. [3] Wang Xi,Lu Rong.The short-term and long-term effects of the four trillion investment plan under the crisis[J].Journal of Sun Yat-sen University (Social Science Edition), 2009, 49(04):180-188.

[4] Guo Jue, Guo Guangtao,Meng Lei,Xue Yong.Measurement and Analysis of the Pull Effect of 4 trillion Investment on China's Economy[J].Management Review,2009,21(02):98-104.

[5] Su Zhi,Li Yuan,Xu Shudan.Optimization of China's Investment Structure under "Structural" Deceleration: An Analysis Based on the Effect of Four Trillion Investment[J].Financial Research, 2013(01):43-47. 